\title{
Physicochemical Characteristics of Non-Starch Polysaccharides Extracted from Cassava Tubers
}

(Ciri Fizikokimia Polisakarida tak Berkanji yang Diekstrak daripada Ubi Kayu)

\author{
UTHUMPORN, U.,* NADIAH, I., IZZUDDIN, I., CHENG, L.H. \& AIDA, H.
}

\begin{abstract}
This research mainly focused on isolation of non-starch polysaccharide (NSP) from different parts of cassava tuber by using water extraction and to evaluate the effect of NSP addition into flour on nutritional composition, swelling and solubility, pasting properties and dough characteristics by farinograph and extensograph. Three origins of (NSP) extracted were used: cassava peels, coarse and fine portions from cassava flesh. The isolation of NSP was done by using water extraction method and designated as water-extractable (WEP) and water un-extractable non starch polysaccharides (WUP). The percentage yield of WEP (0.24 - 1.64\%) from water extraction was significantly lower as compared to WUP (2.58 - 4.33\%). Upon the incorporation of $5 \%$ NSP, the cassava flour showed lower moisture content compared to the sample without the addition of NSP, while fats and crude fiber content of cassava flours were found to be increased upon the incorporation of 5\% NSP from all origins. Swelling power and solubility of cassava flour were being reduced upon the incorporation of $5 \%$ of NSP from cassava peel and coarse portion of cassava flesh. The changes in dough characteristics showed that water absorption of the samples upon the addition of $5 \%$ NSP into wheat flour was found to be higher compared to control wheat flour. In contrast, dough stability and extensibility, tolerance index, resistance to extension, as well as the work input necessary for dough deformation from wheat flour with addition of 5\% NSP resulted lower than control wheat flour. Overall, NSP extracted from cassava peels and coarse portion of cassava flesh performed similar characteristics and functional properties upon the incorporation into the flour.
\end{abstract}

Keywords: Cassava; non starch polysaccharides; water extraction

ABSTRAK

Kajian ini tertumpu kepada pengekstrakan polisakarida tak berkanji (NSP) daripada ubi kayu dan menilai kesannya ke atas komposisi makanan, kuasa pembengkakan dan keterlarutan, ciri kelikatan dan perubahan ciri doh melalui 'farinograf' dan 'ekstensograf'. Tiga jenis NSP yang diekstrak telah digunakan: kulit ubi kayu, bahagian kasar dan halus daripada isi ubi kayu. Pengasingan NSP telah dilakukan dengan menggunakan kaedah pengekstrakan air dan ditetapkan sebagai pengekstrakan air (WEP) dan pengekstrakan air polisakarida tak berkanji (WUP). Peratusan bagi hasil WEP (0.24-1.64\%) adalah lebih rendah berbanding dengan WUP (2.58 - 4.33\%). Kandungan air didapati lebih rendah apabila tepung ubi kayu ditambahkan dengan 5\% NSP berbanding dengan sampel yang tidak ditambahkan NSP, manakala kandungan lemak dan serabut kasar didapati meningkat apabila ditambah dengan 5\% NSP daripada semua bahagian. Kuasa pembengkakan dan keterlarutan tepung ubi kayu menunjukkan penurunan dengan penambahan 5\% NSP daripada kulit ubi kayu dan bahagian kasar isi ubi kayu. Perubahan ke atas ciri doh didapati menunjukkan peningkatan kuasa penyerapan air apabila NSP ditambah ke dalam tepung gandum berbanding tepung gandum kawalan. Namun, kestabilan doh, indeks toleransi, rintangan lanjutan serta perkara yang diperlukan untuk mengubah bentuk doh daripada tepung gandum yang ditambah dengan NSP telah memberi keputusan berkurangan berbanding tepung gandum kawalan. Secara keseluruhan, NSP yang diekstrak daripada kulit ubi kayu serta bahagian kasar daripada isi ubi kayu menunjukkan sifat yang hampir sama apabila ditambahkan ke dalam tepung.

Kata kunci: Pengekstrakan air; polisakarida tak berkanji; ubi kayu

\section{INTRODUCTION}

Recently, increasing attention has been given to the fiber intake in our daily life since research has shown that dietary fiber may benefit health in several different ways. Dietary fiber is the indigestible portion of plant foods which acts by changing the nature of the gastrointestinal tract and determine how other nutrients and chemicals are absorbed into our body system. Chemically, dietary fiber consists mostly of non-starch polysaccharides (NSP) whereby NSP defined as complex polysaccharides other than starch.

NSP is typically long polymeric carbohydrate chains containing up to several hundred thousand monomeric units. They are mostly abundant with celluloses, hemicelluloses as well as pectins, while fructans, glucomannans and galactomannans belong to the group of NSP that are not so abundant within the plant. Mucilages, alginates, exudate 
gums and b-glucans are classified as other constituents of NSP (Sinha et al. 2011; Sun et al. 1999). NSP serve as a marker in dietary guidelines which provide consumers with useful information for food labeling. For health benefits aspect, NSP is functioning significantly in softening stool and it is believed to prevent diabetes, atherosclerosis and lowering cholesterol level as well. In food industry, NSP is used as functional ingredients especially in bakery products to modify the rheological properties and dough characteristics (Mohan et al. 2010). NSP can be normally found in wheat, rye, corn, sorghum, roots, tubers and leaves (Sinha et al. 2011).

Over the years, lots of researches have been done on the characteristics and functional properties of NSP such as from rice (Mohan et al.2010), cereals and millet (Shyama et al. 2004) as well as sago (Sun et al. 1999). To date, the comparison of the extraction of NSP extracted from different parts of cassava root such as peels, coarse and fine portions from its starchy flesh and its characteristic have not been studied extensively. Therefore, the purpose of this paper was designed to investigate the extraction and functional properties of NSP extracted from different parts of cassava roots, as well as the changes in rheological properties and characteristic of dough upon the addition of NSP into food. This would provide some insights on the attribute and property of end products with regards to the addition of NSP as a source of dietary fiber in food industry.

\section{MATERIALS AND METHODS}

\section{RAW MATERIALS AND CHEMICALS}

Cassava tubers were obtained from local market (Penang, Malaysia) to produced cassava flour. Wheat flour was purchased from local market in Penang. Glucoamylase enzyme which used in water extraction of NSP was purchased from Sigma Aldrich (Selangor, Malaysia).

\section{PREPARATION OF CASSAVA FLOUR}

Cassava flours were prepared by adopting the method of Charoenkul et al. (2011) with slight modification. Cassava roots were washed and peeled. The peels and flesh of the cassava were chipped into a uniform size by a chipper. The peels and flesh were then dried in hot air oven at $50^{\circ} \mathrm{C}$ for $24 \mathrm{~h}$. After $24 \mathrm{~h}$, the peels and flesh, respectively, were milled by centrifugal mill for 3 min to make flours. The flours from cassava flesh were then sieved through at 250 $\mu \mathrm{m}$ aperture, sieved by sieve machine at a speed of $80 \mathrm{rpm}$ for $15 \mathrm{~min}$ to get the fine and coarse portions.

\section{WATER EXTRACTION OF NSP}

The extractions of NSP were done by adopting the method of Shyama et al. (2004) with slight modification. WEP (water extractable NSP) were isolated by extracting cassava flours (peels, coarse and fine portion from its flesh), $100 \mathrm{~g}$ each with deionized water $(200 \mathrm{~mL} \times 4)$ and centrifuged at 130 $\mathrm{rpm}$ at $60^{\circ} \mathrm{C}$ in water bath for $20 \mathrm{~min}$. The supernatant was precipitated with three volumes of approximately $96 \%$ ethanol and centrifuged $10 \mathrm{~min}$ at $2000 \times \mathrm{g}$ at $25^{\circ} \mathrm{C}$. The supernatant was put into water bath at $60^{\circ} \mathrm{C}$ to evaporate the ethanol and then lyophilized by freeze dryer and designated as WEP. The residue obtained after centrifugation was digested with glucoamylase ( $1 \mathrm{~g} / 100 \mathrm{~g}$ of material) for 48 $\mathrm{h}$ at $55^{\circ} \mathrm{C}$ in obito shaker at $130 \mathrm{rpm}$ to remove the starch completely. The sample was then heated at $100^{\circ} \mathrm{C}$ for 10 min to inactivate the glucoamylase enzyme and designated as WUP (water un-extractable NSP).

\section{PERCENTAGE YIELD OF NSP}

NSP extracted from cassava peels, coarse and fine portions from flesh were weighed and recorded accurately. The calculation is shown as below:

$$
\text { Yield }(\%)=\frac{\text { Yields of NSP }}{\text { Weight of flour (cassava) }} \times 100 \%
$$

\section{DETERMINATION OF MOISTURE}

The moisture content of starch samples were determined by using moisture analyzer (MX-50). Approximately $5 \mathrm{~g}$ of starch samples were spread uniformly in a pre-dried aluminium pan onto a moisture analyzer set at $105^{\circ} \mathrm{C}$ for drying. All the samples were analyzed in triplicate. The result was presented as percentage (\%) of moisture content.

\section{DETERMINATION OF FAT}

Fat content of starch samples were determined by Soxhlet method, number 960.39 (AOAC 1996).

\section{DETERMINATION OF CRUDE FIBER}

Crude fiber content of starch samples were determined by enzymatic-Gravimetric Method, number 991.43 (AOAC 1996).

\section{SWELLING AND SOLUBILITY}

Swelling and solubility of starch were determined by adopting the method of Schoch (1964). Approximately $0.5 \mathrm{~g}$ of starch samples were mixed with $25 \mathrm{~mL}$ distilled water in a centrifuge tube and heated at $85^{\circ} \mathrm{C}$ in a shaking water bath for $30 \mathrm{~min}$. The starch solution was cooled to room temperature and then centrifuged (5100 KUBOTA, Tokyo, Japan) for $15 \mathrm{~min}$ at $3500 \mathrm{rpm}$. After centrifugation, swelling was determined as sediment weight $(\mathrm{g} / \mathrm{g})$, while the supernatant was used for measuring solubility of starch. The supernatant was carefully decanted by transferred to weighted moisture dish and dried overnight at $105^{\circ} \mathrm{C}$ in an oven. Solubility was calculated. The swollen starch sediment in the tube was weighed. Swelling and solubility of the starches were calculated using the following formula;

$$
\text { Swelling }(\mathrm{g} / \mathrm{g})=\frac{\text { Weight of wet sediment }(g)}{\text { Weight of initial dry starch }(g)} \text {, }
$$


Solubility $(\%)=\frac{\text { Weight of dry supernatant }(g)}{\text { Weight of initial dry starch }(g)} \times 100 \%$

\section{PASTING PROPERTIES}

Pasting properties of starch samples were measure using Rapid Visco Analyser (RVA) (Model RVA-4; Newport Scientific, Warriewood, Australia). The starch-water suspensions (8\% (w/w), dry starch basis) were monitored. $2 \mathrm{~g}$ of starch samples and $25 \mathrm{~mL}$ distilled water is added in aluminum RVA sample canister. Temperature was held at $50^{\circ} \mathrm{C}$ in $3.75 \mathrm{~min}$ and then raised to $95^{\circ} \mathrm{C}$ in $3.75 \mathrm{~min}$, held for $2.5 \mathrm{~min}$, cooled at $50^{\circ} \mathrm{C}$ in $3.75 \mathrm{~min}$ and held for $5 \mathrm{~min}$. The paddle speed was set at $960 \mathrm{rpm}$ for the first $10 \mathrm{~s}$ to evenly disperse the starch slurry and reduced to $160 \mathrm{rpm}$ throughout the entire experiment. The units of viscosity were expressed as RVU.

\section{FARINOGRAPH}

In farinograph, NSP were added into wheat flour. Water absorption and mixing properties of wheat dough were determined by Brabender Farinograph as described by Suba Rao et al. (2004) with slight modification. The following parameters were determined from the resulting farinogram: \% of water absorption on $500 \mathrm{FU}$, dough development time (DDT), dough stability (DS) and mixing tolerance index (MTI).

\section{EXTENSOGRAPH}

Extensograph analysis was carried out by Brabender extensograph as described by Suba Rao et al. (2004) with slight modification, by using dough with 500 BU consistencies.

\section{STATISTICAL ANALYSIS}

All experiments were carried out in triplicates. Data were analyzed using one-way analysis of variance (ANOVA) to obtained mean values and standard deviations. Duncan's Multiple Range test $(p<0.005)$ was used to determine the significant differences among the samples by using Statistical Package Social Science (SPSS) 17.0 for Window Evaluation Version.

\section{RESULTS AND DISCUSSION}

\section{PERCENTAGE YIELD OF NSP}

The percentage yield of WEP (0.24 to $1.64 \%)$ from water extraction was lower as compared to WUP (2.58 to $4.33 \%)$. Thus, the further characterizations of NSP from different parts of cassava tuber were only carried out on WUP due to the lower percentage yield of WEP.

\section{DETERMINATION OF MOISTURE, FAT AND CRUDE FIBER}

Moisture content of the samples with or without the addition of NSP ranged from $8.46-8.87 \%$ as shown in Table 1 . The results obtained were consistent with the results reported by Aryee et al. (2006). Addition of 5\% NSP extracted from cassava peal and coarse portion of cassava flesh showed significant decrease $(p<0.05)$ in moisture content compared to control cassava flour. However, the sample with the addition 5\% NSP from fine portion of cassava flesh has the highest moisture content compared to the other samples. According to Adetan et al. (2003), the starchy flesh of cassava which mostly make up for the fine portions is surrounded by a thin cambium layer, cortex as well as corky periderm (tuber peels). The tuber peels and cambium layer serve to seal the tuber surface. It is probably suggested that the moisture content in starchy flesh was higher due to the sealing effect of tuber peels and cambium layer which aids in blocking the moisture from being lost. Therefore, samples with the addition of $5 \%$ NSP from fine portion of cassava flesh showed the highest moisture content.

The results showed that fat contents of cassava flour did not change much for cassava flour with addition of 5\% NSP from cassava peel and fine portion of cassava flesh. In contrast, the fat content in cassava flour with addition of $5 \%$ NSP from coarse portion of cassava flesh showed the highest value compared to the other samples. According to Swinkels (1985), cassava starch contained low level of residual components such as proteins and fats, with an average below $2 \%$ (dry weight basis). The low level of proteins and fats is a vital factor in differentiating between cassava starch and cereal starch. Apart from that, low level of proteins and fats make cassava has its own unique value whereby the starch from cassava roots is inexpensive to extract.

TABLE 1. Moisture, fat and crude fiber content of cassava flour with or without the addition of NSP

\begin{tabular}{|c|c|c|c|}
\hline Samples & Moisture content $(\%)$ & Fat content $(\%)$ & Crude fiber $(\%)$ \\
\hline Control cassava flour & $8.64 \pm 0.04^{\mathrm{b}}$ & $1.08 \pm 0.17^{\mathrm{a}}$ & $1.06 \pm 0.13^{\mathrm{a}}$ \\
\hline $\begin{array}{c}\text { Cassava flour with addition of } \\
5 \% \text { NSP from cassava peel }\end{array}$ & $8.46 \pm 0.04^{\mathrm{a}}$ & $1.15 \pm 0.18^{\mathrm{a}}$ & $2.19 \pm 0.03^{c}$ \\
\hline $\begin{array}{c}\text { Cassava flour with addition of } \\
5 \% \text { NSP from coarse flesh }\end{array}$ & $8.50 \pm 0.02^{\mathrm{a}}$ & $1.46 \pm 0.16^{\mathrm{b}}$ & $1.80 \pm 0.05^{\mathrm{b}}$ \\
\hline $\begin{array}{l}\text { Cassava flour with addition of } \\
5 \% \text { NSP from fine flesh }\end{array}$ & $8.87 \pm 0.05^{\mathrm{c}}$ & $0.86 \pm 0.10^{\mathrm{a}}$ & $1.21 \pm 0.13^{\mathrm{a}}$ \\
\hline
\end{tabular}

Values are mean \pm standard deviation $(n=3)$ and with different superscript letters are differ significantly $(p<0.05)$ 
Dietary fiber is a general term used to describe the food components which are indigestible in small intestine. NSP is the majority part of dietary fiber which generally composes of water insoluble fraction, which is also known as crude fiber as well as water soluble fraction (Sasaki et al. 2000). Result from Table 1 shows that cassava flour with addition of 5\% NSP from cassava peel has the highest crude fiber content $(2.19 \pm 0.03 \%)$, followed by cassava flour with addition of $5 \%$ NSP from coarse portion of cassava flesh $(1.80 \pm 0.05 \%)$, cassava flour with addition of $5 \%$ NSP from fine portion of cassava flesh $(1.21 \pm 0.13 \%)$ and lastly, control cassava flour $(1.06 \pm 0.13 \%)$.

\section{SWELLING AND SOLUBILITY}

From the result in Table 2, the swelling power of the starch granules in cassava flour with addition of $5 \%$ NSP from fine portion of cassava flesh showed the highest $(9.01 \pm 0.41$ $\mathrm{g} / \mathrm{g})$, followed by control cassava flour $(7.90 \pm 0.16 \mathrm{~g} / \mathrm{g})$, cassava flour with addition of 5\% NSP from coarse portion of cassava flesh $(7.21 \pm 0.13 \mathrm{~g} / \mathrm{g})$ and lastly cassava flour with addition of $5 \%$ NSP from cassava peel $(6.59 \pm 0.41$ $\mathrm{g} / \mathrm{g}$ ). Upon the addition of NSP from peels and coarse portion, the swelling power of the cassava starch was reduced significantly. According to Sasaki et al. (2004), differences in amylose content significantly affected the swelling power of starch granules. Besides, Gomand et al. (2010) also reported that starch with higher amylose content underwent restricted swelling and further support the previous work done by Tester and Morrisonn (1990). Besides, according to Charles et al. (2007), protein content could reduce swelling power and solubility of starch granules. NSP is a major component of dietary fiber which mostly made up with celluloses, hemicelluloses and pectin (Sinha et al. 2011; Sun et al. 1999). As protein is a part of the components of NSP, presumably, the addition of NSP into the cassava flour would probably reduce the swelling power and solubility of the starch granules as a consequence. With the presence of gum and mucilage in the starch-water system, water mobility is being restricted. As gums and mucilage are parts of NSP components (Sinha et al. 2011; Sun et al. 1999), the inclusion of NSP into the system will reduce the volume fraction of water as well as limiting water availability for starch granules and followed by further restriction in gelatinization process. NSP probably restricts gelatinization by reducing hydration of the amorphous region. Similar study has been conducted by Sasaki et al (2000) who revealed that addition of NSP would inhibit starch swelling.

\section{PASTING PROPERTIES}

From the results obtained in Table 3, the peak temperature of the control cassava flour was the highest $\left(98.7 \pm 0.6^{\circ} \mathrm{C}\right)$, followed by cassava flour with addition of $5 \%$ NSP from cassava peel $\left(98.3 \pm 0.8^{\circ} \mathrm{C}\right)$, cassava flour with addition of $5 \%$ NSP from fine portion of cassava flesh $\left(95.7 \pm 1.0^{\circ} \mathrm{C}\right)$ and lastly cassava flour with addition of $5 \%$ NSP from coarse portion of cassava flesh $\left(95.5 \pm 1.0^{\circ} \mathrm{C}\right)$. Upon the addition of $5 \%$ of NSP, the paste viscosity of the starch was significantly reduced. Thus, lower temperature is needed to achieve peak viscosity. The control cassava flour sample showed the highest paste viscosity because starch granules can rapidly pick up water, swell and develop the viscosity

TABLE 2. Swelling and solubility of cassava flour with or without the addition of NSP

\begin{tabular}{lcc}
\hline Sample & Swelling $(\mathrm{g} / \mathrm{g})$ & Solubility $(\%)$ \\
\hline $\begin{array}{l}\text { Control cassava flour } \\
\text { Cassava flour with addition of 5\% NSP } \\
\quad \text { from cassava peel }\end{array}$ & $7.90 \pm 0.16^{\mathrm{c}}$ & $9.49 \pm 0.05^{\mathrm{b}}$ \\
$\begin{array}{l}\text { Cassava flour with addition of 5\% NSP } \\
\quad \text { from coarse flesh }\end{array}$ & $6.59 \pm 0.41^{\mathrm{a}}$ & $9.21 \pm 0.22^{\mathrm{a}}$ \\
$\begin{array}{l}\text { Cassava flour with addition of 5\% NSP } \\
\quad \text { from fine flesh }\end{array}$ & $7.21 \pm 0.13^{\mathrm{b}}$ & $9.31 \pm 0.07^{\mathrm{ab}}$ \\
\hline
\end{tabular}

Values are mean \pm standard deviation $(n=3)$ and with different superscript letters are differ significantly $(p<0.05)$

TABLE 3. Pasting properties of cassava flour with or without the addition of NSP determined by a RVA

\begin{tabular}{lcccc}
\hline Sample & $\begin{array}{c}\text { Peak temperature } \\
\left({ }^{\circ} \mathrm{C}\right)\end{array}$ & Peak viscosity & $\begin{array}{c}\text { Breakdown } \\
(\text { RVU })\end{array}$ & Setback \\
\hline $\begin{array}{l}\text { Control cassava flour } \\
\text { Cassava flour with addition of 5\% }\end{array}$ & $98.7 \pm 0.6^{\mathrm{b}}$ & $97.50 \pm 0.87^{\mathrm{c}}$ & $28.36 \pm 0.55^{\mathrm{c}}$ & $25.14 \pm 0.27^{\mathrm{b}}$ \\
$\quad \begin{array}{l}\text { NSP from cassava peel } \\
\text { Cassava flour with addition of 5\% } \\
\quad \text { NSP from coarse flesh }\end{array}$ & $98.3 \pm 0.8^{\mathrm{b}}$ & $86.72 \pm 1.19^{\mathrm{a}}$ & $21.83 \pm 0.58^{\mathrm{a}}$ & $22.92 \pm 0.71^{\mathrm{a}}$ \\
$\begin{array}{l}\text { Cassava flour with addition of 5\% } \\
\quad \text { NSP from fine flesh }\end{array}$ & $95.5 \pm 1.0^{\mathrm{a}}$ & $91.95 \pm 1.54^{\mathrm{b}}$ & $24.36 \pm 0.92^{\mathrm{b}}$ & $24.67 \pm 0.94^{\mathrm{b}}$ \\
\hline
\end{tabular}

Values are mean \pm standard deviation $(n=3)$ and with different superscript letters are differ significantly $(p<0.05)$ 
with the absence of NSP. Besides, there were no foreign substances present to disturb the leaching of amylose and thus lower the starch content in the sample (Tester \& Morrison 1990). NSP would probably cause a reduction with the amount of leachate (mainly amylose) which tends to reduce the peak viscosity of the starch (Tester \& Sommerville 2003).

According to Zaidul et al. (2007), peak viscosity, final viscosity and breakdown viscosity increased significantly with the increase of starch level. Therefore, starch level in the samples will be reduced upon the addition of NSP. Presumably, with lower starch level, the paste viscosities were reduced, as can be observed from results which shown in Table 3. Besides, results also showed that the setback value of the control cassava flour sample was among the highest compared to the other samples incorporation with $5 \%$ NSP. The higher value of setback could probably due to the formation of network resulting from the leached amylose molecules (Gomand et al. 2010).

\section{FARINOGRAPH}

Based on the results from Table 4, water absorption of the wheat flour samples with the addition of NSP was found to be higher compared to the control wheat flour. NSP is a major part of the dietary fiber, are able to absorb considerable amount of water due to the interaction of the hydroxyl group in fiber structure with water through hydrogen bonds (Rosell et al. 2001). However, the incorporation of 5\% NSP from fine portion into the wheat flour only contributed to a slight improvement of dough water absorption. The results demonstrated is also supported by Rosell et al. (2001), which reported that water absorption and other indices characterizing the dough mixing properties were strongly related to the doses applied as well as the type of addition. Delcour et al. (1991) suggested that the dough development time and dough stability were determined by the starchgluten network. Gluten development gave the dough an elasticity structure. The incorporation of NSP would decrease the wheat flour portions and further increase the no-gluten-forming proteins in the flour, resulting in a weaker structure as compared to $100 \%$ wheat flour dough. Consequently, the gluten development time will be shortened (Nindjin et al. 2011). However, an opposite effect occurred with the dough development time in wheat flour with addition of 5\% NSP from cassava peal as shown in Table 4, which probably due to the competition of water and further delayed the gluten development (Rosell et al. 2001). Apart from that, the values of tolerance index were reduced upon the addition of NSP into the dough.

\section{EXTENSOGRAPH}

From the result obtained in Table 5, the incorporation of NSP into wheat flour yielded a decrease in dough extensibility. As discussed before, NSP are able to absorb considerable amount of water due to the interaction of the hydroxyl group in fiber structure with water through hydrogen bonds (Rosell et al. 2001). The absorption of water caused gluten diluting and further reduced the dough extensibility. Apart from that, it was observed that the maximum extensibility of the dough was decreased sharply from 45 to $90 \mathrm{~min}$, while there was only a gradual decrease from 90 to 135 min. The results implied that there is a weaker effect on the extensibility of dough with extended proving time.

Furthermore, there was also significant decrease in resistance to extension upon the incorporation of NSP into the wheat flour. The reduction in resistance was notably greater in wheat flour with addition of 5\% NSP from coarse portion of cassava flesh. The incorporation of NSP reduced the wheat flour portion which is responsible in forming gluten network structure (Nindjin et al. 2011). Consequently, the dough structure was subjected to loosening as well as losing its strains resistance. On the other hand, the area (energy or work input necessary for dough deformation) was strongly correlated with the resistance to extension, in the case that more work input is needed with increase in strains resistance. However, the decrease trend of work input was not consistent as proving time increase. Thus, result concluded that proving time had only slight modifying effect on work input necessary for dough deformation.

TABLE 4. Dough characteristics of wheat flour with or without the addition of NSP by farinograph

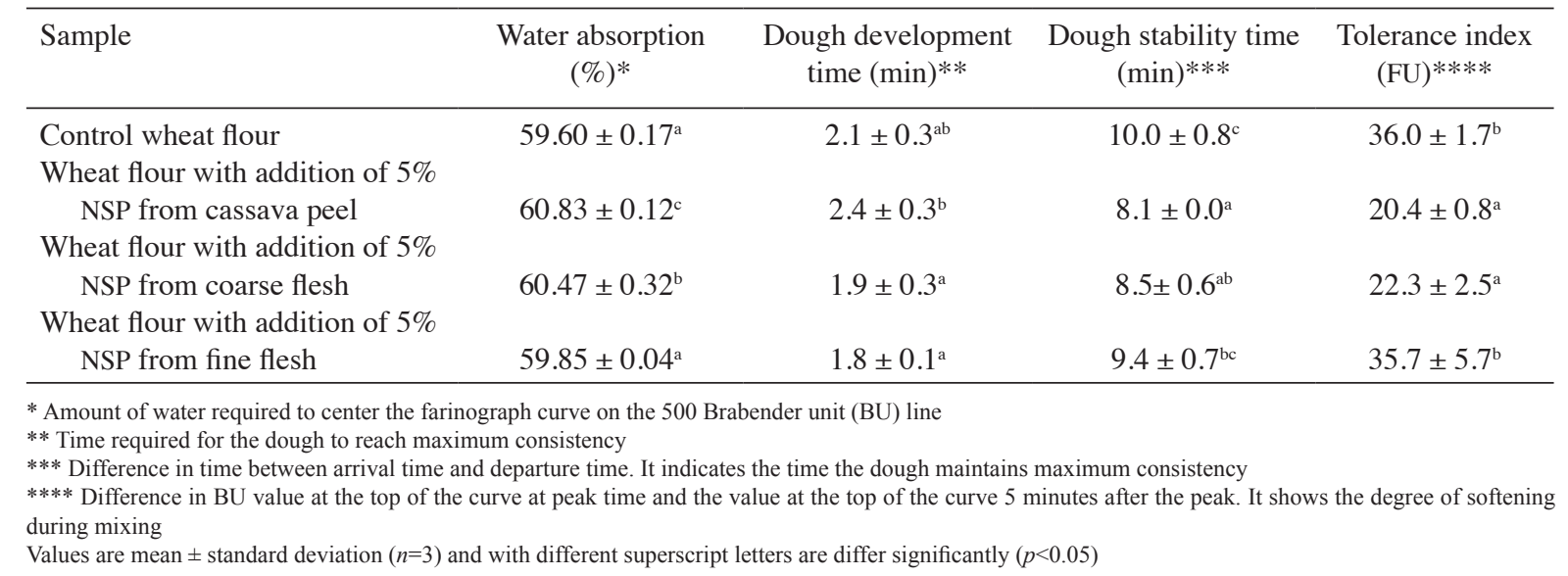




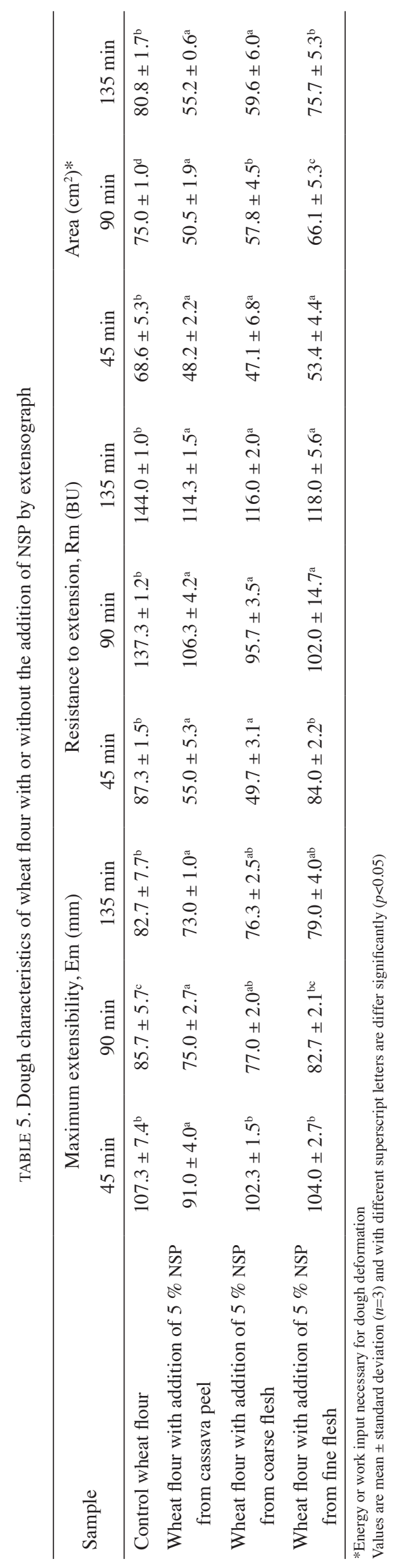




\section{CONCLUSION}

The percentage yield of WEP was far lower as compared to WUP. Upon the incorporation of NSP into flour, crude fiber content was found to be higher. Crude fiber is basically the insoluble portions of NSP which is metabolically inert, absorbing water as it moves through the digestive system. NSP serve as a marker in dietary guidelines which provide consumers with useful information for food labeling. Thus, the incorporation of NSP as a functional ingredient in food industry not only benefits our health but it is also found to modify the rheological properties as well as dough characteristics in bakery products. In this research, NSP extracted from coarse portions of cassava flesh, presumably serves as a better functional ingredient in food industry with its higher yield of extraction as well as other desirable characteristics in terms of swelling and solubility, pasting properties and dough characteristics as compared to NSP extracted from cassava peels. The doses of the incorporation have to be taken into account as well because studies have shown that the doses of NSP applied might resulted in a more extensible, but at the same time, mechanically weaker structure of dough, or in the opposite way.

\section{ACKNOWLEDGEMENTS}

This work was supported by Universiti Sains Malaysia Short Term Grant Research: 304/PTEKIND/6311131.

\section{REFERENCES}

Adetan,D.A.,Adekoya,L.O.\&Aluko,O.B. 2003. Characterization of some properties of cassava root tubers. Journal of Food Engineering 59: 349-353.

AOAC. 1996. Official Method of Analysis of the Association of Official Analytical Chemists. 14th ed. Arlington, Virginia: AOAC International.

Aryee, F.N.A., Oduro, I., Ellis, W.O. \& Afuakwa, J.J. 2006. The physicochemical properties of flour samples from the roots of 31 varieties of cassava. Food Control 17: 916-922.

Charles, A.L., Huang, T.C., Lai, P.Y., Chen, C.C., Lee, P.P. \& Chang, Y.H. 2007. Study of wheat flour-cassava starch composite mix and the function of cassava mucilage in Chinese noodles. Food Hydrocolloids 21: 368-378.

Charoenkul, N., Uttapap, D., Pathipanawat, W. \& Takeda, Y. 2011. Physicochemical characteristics of starches and flours from cassava varieties having different cooked root textures. Food Science and Technology 44: 1774-1781.

Delcour, J.A., Martens, A., Schellekens, M., De Geest, C. \& Defloor, I. 1991. Emulsifiers and/ or extruded starch in the production of breads from cassava. Cereal Chem. 64: 323-327.

Gomand, S.V., Lamberts, L., Visser, R.G.F. \& Delcour, J.A. 2010. Physicochemical properties of potato and cassava starches and their mutants in relation to their structural properties. Food Hydrocolloids 24: 424-433.

Mohan, B.H., Malleshi, N.G. \& Koseki, T. 2010. Physicochemical characteristics and non-starch polysaccharide contents of Indica and Japonica brown rice and their malts. Food Science and Technology 43: 784-791.
Nindjin, C., Amani, G.N.\& Sindic, M. 2011. Effect of blend levels on composite wheat doughs performance made from yam and cassava native starches and bread quality. Carbohydrate Polymers 86: 1637-1645.

Rosell, C.M., Rojas, J.A. \& Benedito de Barber, C. 2001 . Influence of hydrocolloids on dough rheology and bread quality. Food Hydrocolloids 15: 75-81.

Sasaki, T., Kohyama, K. \& Yasui, T. 2004. Effect of water-soluble and insoluble non-starch polysaccharides isolated from wheat flour on the rheological properties of wheat starch gel. Carbohydrate Polymers 57: 451-458.

Sasaki, T., Yasui, T. \& Matsuki, J. 2000. Influence of non-starch polysaccharides isolated from wheat flour on the gelatinization and gelation of wheat starches. Food Hydrocolloids 14: 295303.

Schoch, T.J. 1964. Swelling power and solubility of granular starches. In Methods in Carbohydrate Chemistry, Vol.4. edited by Whistler, R.L., Smith, R.J. \& BeMiller, J.N. New York: Academic Press. pp. 106-108.

Shyama,P.R., Manohar, R.S.\& Muralikrishna, G. 2004.Functional properties of water-soluble non-starch polysaccharides from rice and ragi: Effect on dough characteristics and baking quality. LWT 40: 1678-1686.

Sinha, A.K., Kumar, V., Makkar, H.P.S., Boeck, G.D. \& Becker, K. 2011. Non starch polysaccharides and their role in fish nutrition- A review. Food Chemistry 127: 1409-1426.

Suba Rao, M.V.S.S.T., Sai Manohar,R.\& Muralikrishna, G. 2004. Functional characteristics of non-starch polysaccharides (NSP) obtained from native (n) and malted (m) finger millet. Food Chemistry 88: 453-460.

Sun, R.C., Jones, G.L., Tomkinson, J. \& Bolton, J. 1999. Fractional isolation and partial characterization of non-starch polysaccharides and lignin from sago pith. Industrial Crops and Products 19: 211-220.

Swinkels, J.J.M. 1985. Composition and properties of commercial native starches. Starch/ Stäeke 37: 1-5.

Tester, R.F. \& Morrison, W.R. 1990. Swelling and gelatinization of cereal starches 1. Effects of amylopectin, amylose, and lipids. Cereal Chemistry 67: 551-557.

Tester, R.F. \& Sommerville, M.D. 2003. The effects on non starch polysaccharides on the extent of gelatinization, swelling and $\alpha$-amylase hydrolysis of maize and wheat starches. Food Hydrocolloids 17: 41-54.

Zaidul, I.S.M., Nik Norulaini, N.A., Mohd. Omar,A.K., Yamauchi, H. \& Noda, T. 2007. RVA analysis of mixtures of wheat flour and potato, sweet potato, yam, and cassava starches. Carbohydrate Polymers 69: 784-791.

Uthumporn, U.,* Nadiah, I., Izzuddin, I. \& Cheng, L.H. Food Technology Division, School of Industrial Technology Universiti Sains Malaysia, 11800 Penang, Pulau Pinang Malaysia

Aida, $\mathrm{H}$

Food Technology Centre, MARDI Headquarters

Serdang, G.P.O. Box 12301

50774 Kuala Lumpur

Malaysia

*Corresponding author; email: sapina@usm.my

Received: 23 May 2014

Accepted: 10 May 2016 